\title{
A Self-Study on The Values and Beliefs of Science Teachers and Their Science, Technology, Engineering and Mathematics (STEM) Applications
}

\author{
İsmail DÖNMEZ* \\ Child Development Department, Muş Alparslan University, Muş, Turkey, 0000-0002-7792- \\ 0169 \\ Mehmet Fatih TAŞAR \\ Department of Science Education, Gazi University, Ankara, Turkey, 0000-0003-1249-3482
}

\begin{tabular}{|c|c|}
\hline Article & \multirow{7}{*}{$\begin{array}{l}\text { The aim of this research is to understand how the values and beliefs of } \\
\text { science teachers reveal in the classes where STEM activities are applied. } \\
\text { For this purpose, a researcher and two science teachers applied STEM } \\
\text { activities developed by the researcher for } 14 \text { weeks in science } \\
\text { applications classes. The science teachers and the researcher work in } \\
\text { socio-economically different districts of Ankara, Turkey. In this study, } \\
\text { one of the qualitative research methods, self-study design was used. Self- } \\
\text { study is a research design that contributes to the teacher's understanding } \\
\text { of himself/herself, questioning own practice and professional } \\
\text { development by becoming a researcher. Data sources are the life stories } \\
\text { of the researcher and the participating teachers, in-class video recordings } \\
\text { and post-lesson diaries. The obtained data were analyzed by narrative } \\
\text { and content analysis. It was understood from their life stories that } \\
\text { environmental and socio-cultural factors were effective in science } \\
\text { teachers' choosing their profession. It was seen that there were internal } \\
\text { and external factors affecting the values and beliefs of science teachers. } \\
\text { As a result, it was seen that the researcher improved himself in terms of } \\
\text { classroom management in the classes where STEM activities were } \\
\text { applied, and that there was a close relation between values and beliefs } \\
\text { and their practices. }\end{array}$} \\
\hline Recei & \\
\hline & \\
\hline $\begin{array}{l}\text { Received in } \\
22.01 .2020\end{array}$ & \\
\hline & \\
\hline & \\
\hline & \\
\hline
\end{tabular}

\section{Introduction}

The importance and popularity of STEM (science, technology, engineering, mathematics) education has been increasing in recent years. In this context, countries are trying to include STEM education in their education programs and course contents. Although many steps have been taken to develop STEM education at primary and secondary level, few of these are aimed at the professional development of teachers. In fact, the competency of a teacher is considered to be an important factor to succeed in many educational reforms such as the integration of STEM education. Teachers' competencies here are defined as professional knowledge, professional skills and attitudes-values, which are necessary for the teachers to perform their profession efficiently. Even though the literature emphasizes the importance of teachers in STEM education and pinpoints the need for teachers to develop STEM thinking (NRC, 2011b), STEM teacher development in general has not yet been well defined or carefully 
studied up to date (Rinke, Gladstone-Brown, Kinlaw \& Cappiello,2016). Investigating the education, beliefs and practices of teachers within the framework of STEM education will contribute to the studies to be conducted in this field. The first concept about teacher education is pedagogical field knowledge. Pedagogical Content Knowledge (PCK) is a term defined by Shulman (1986). What distinguishes a teacher from an expert of the subject? Or, in other words, "what does a math teacher do with what a history teacher cannot do?" Shulman tries to find an answer to such questions and states that knowing pedagogy is as important as the knowledge of field, and that these two structures of knowledge should be combined to become effective teachers. It is witnessed that the original model developed by Shulman does not include the components such as teaching orientation suggested by Grossman (1990). Within the scope of pedagogical knowledge, Grossman (1990) focused on: (i) learners and beliefs related to learning, (ii) classroom management, (iii) curriculum, (iv) beliefs and knowledge of the aims and objectives of education. Grossman also defined context information as; (i) the opportunities in the region where the teacher works, (ii) expectations and limitations, (iii) the school environment and the families of the students, (iv) information about the interests and backgrounds of the students. Today, approaches which support technology knowledge with field knowledge and field-specific pedagogical method knowledge are proposed instead of the programs where technology integration knowledge is limited merely to technology courses (Mishra \& Koehler, 2006). The main problem with the educational approaches of traditional technology integration is that these approaches:1) focus on teaching technology instead of teaching with technology, address the technology independently from the concept of pedagogical field knowledge (PFK), 3. do not emphasize the complex structure of technology integration knowledge, and 4. Focus on general solutions independent of context (Mishra \& Koehler, 2006).

However, in order for teachers to be able to adapt to a comprehensive understanding like TPAB, they need to continue their professional development in the field of teaching practices. For professional development, teachers should focus on student learning and they should also be questioning and reflective. They should try to develop their content knowledge focusing on practical pedagogical skills and taking advantage of school leaders and external experts (Widjaja, Colleen, Groves \& Doig, 2015). According to Sprinthall, Reiman \& Thies-Sprinthall (1996), there are three basic models used to explain the professional development of teachers. These are; the skill model in which knowledge emerges from classroom experiences, the expert model where teachers are taught what to do by experts, and the interactive model in which teachers are actively involved in meaningful learning. Clarke and Hollingsworth (2002) refer to the professionalization of teachers as "an interdependent professional development model". Studies show that there is a strong link between their beliefs, practices and the development models. According to Brown and Cooney (1982), belief is the tendency of action and the main determinant of behaviour. Pajares (1992) defines belief as the best indicator of individuals' decisions in their lives. According to Kagan (1992), as teachers' experience in the classroom increases, their knowledge increases, and they personalize their teaching beliefs that control their teaching perceptions, decisions and behaviours. Teachers' beliefs are one of the most important factors that affect the regulation and direction of the teaching-learning process (Anagün, Yalçınkaya \& Ergün, 2012). Studies in the process show that the factors such as (a) constructivism (b) curriculum (c) objectives of science education (d) investigation (e) nature (f) reform, (g) science, technology and society (h) teaching and learning and (i) thematic units impact the link between the beliefs and practices of teachers (Savaşçı \& Berlin, 2012). Teacher beliefs are expressed by Buehl and Beck (2015) as (1) filtering and interpreting information, (2) lines of specific task or problem (lesson planning) and (3) interactions. Teachers' beliefs are also related to the novel approaches such as literacy, mathematics, biology or research- 
inquiry and STEM (Buehl \& Beck, 2015). There are many studies found in the relevant literature examining the relationship between belief-value and practices of teachers. One of these studies was conducted by Wilkins (2008) and it showed that the beliefs of 481 American primary-school teachers regarding the effectiveness of the research-questioning approach were the strongest direct predictor of the research-questioning approach. Brown, Harris and Harnett (2012) pointed out that primary school teachers' opinions about feedback were different from feedback practices. Tsangaridou (2008) stated in his study that there is a strong link between the beliefs and practices of two newly started teachers. On the other hand, Jorgensen, Grootenboer, Niesche, and Lerman (2010) evaluated 25 teachers' beliefs about various pedagogical practices through a questionnaire, recorded their practices on video and analyzed their records (eg, the importance of inclusion / culture, group work, ideas). Finally, they found four discrepancies between teachers' beliefs and their practices. Buehl \& Beck, (2015) show the limitations of internal and external factors which influence the teachers' beliefs and practices. Internal Factors here are: The aspects of the teacher's own belief system may facilitate or hinder the practice of those beliefs. The ability of the teachers and their self-efficacy beliefs may explain some of the inconsistencies between teachers' beliefs and practices (OganBekiroglu \& Akkoc, 2009; Tang, Lee, \& Chun, 2012). They suggest that teachers' sense of responsibility can alleviate the relationship between teacher practices and beliefs about the students and the teachers' real-class practices (that is to say teachers will be aligned with their beliefs and the students' results when they feel responsible for them). In particular, teachers' beliefs in improving the abilities and motivations of the students (Mouza, 2009; Turner, Warzon \& Christensen, 2011), and their beliefs about students' profitability, expectations and needs (Nishino, 2012; Southerland, Gallard \& Callihan 2011; Tang et al., 2012) were identified as important in various contexts. In order to build students' beliefs, teachers need to have the necessary knowledge. Mouza (2009) emphasizes the importance of content knowledge, pedagogical knowledge and pedagogical content knowledge so as to enable teachers for them to implement their beliefs in teaching technology which was developed during their professional development experience. The teachers' level of self-knowledge, self-assessment, and self-reflection are other factors related to the harmony between their beliefs and practices. Bryan (2012) emphasises that teachers' beliefs about themselves as supporters of knowledge and their students affect their classroom practices. Laplante (1997) reported that two Canadian primary school teachers' epistemological beliefs had an impact on their choice of teaching strategies. External Factors here are explained as the following: In many cases, it is seen that external factors are effective in teachers' beliefs and practices. Some examples of these external factors are solid accountability, time-effectiveness culture, compulsory curriculum, and state and national assessments. (Bryan, 2012). Some examples of these factors in the classroom context are student attitudes (Bullock, 2010), classroom management (Phipps \& Borg, 2009), and student ability (Savasci \& Berlin, 2012). To cite an example, Savasci and Berlin (2012) articulated that as students' age group increased, teachers could apply constructivist practices in a relatively easier way. Teachers' attitudes and preferences towards students as well as their general attitudes and behaviours affect the overall practices of teachers (Bullock, 2010). In the studies of constructivist beliefs, teachers underlined that they did not apply the inquiry approach because the students were reluctant to think at a high level (Kang, 2008). Savaşci and Berlin (2012) stated that constructivist-oriented secondary school teachers were reluctant to do group work because of student misbehaviour. Another factor that was influential in teachers' practices was class sizes (Uzuntiryaki, Boz \& Kirbulut, 2010). Management, parental support, colleagues and the resources available in the school can indeed support or prevent the relationship between teachers' beliefs and practices (Southerland, Gallard \& Callihan, 2011). The role of the school culture and its community are other parameters that can support or hinder teachers' beliefs. To illustrate, Ciani, Summers \& Easter (2008) investigated how a school-wide performance goal 
affects teachers' collective self-efficacy and teaching practices. In high-performance-oriented schools i.e. the ones promoting students' academic competitiveness, it was found that teachers have lower self-efficacy for the target structure of teaching, classroom management, perceived collective impact, teacher community, and perceived mastery school. The factors at a national, state and county level, educational policies and curriculum standards can create some challenges for teachers in the United States and abroad in implementing the activities in the way that is consistent with their beliefs (Cincotta-Segi, 2011). However, the impact of these external factors depends on the type of the policy, the role of teachers in the political context, and the individual perceptions of the teachers. Curriculum standards put pressure on the school administrators, teachers and the content coverage of teachers in field-based experiences (Buehl \& Beck, 2015). According to Brynn (2012), if teachers can review their beliefs and practices, it will provide them with great opportunities to express their beliefs in their practices and in philosophical foundations of reformation and see their own practices accordingly. This research is believed to contribute to determining the values and beliefs of myself as a science teacher and the participating teachers, to observe how these beliefs-values and practices are revealed or not, to monitor the development of the practices in the classroom:

a) What are my values and beliefs as a science teacher? How do these values and beliefs become apparent in the classroom where I use the STEM applications?

b) How do the Values and Beliefs of the Participant Science Teachers Coded as 'Moon'" are revealed in the classes where Science, Technology, Engineering and Mathematics (STEM) Activities are Applied? What Can I Learn from these?

c) How do the Values and Beliefs of the Participating Science Teachers Coded as "Sun" are revealed in the classes where Science, Technology, Engineering and Mathematics (STEM) Activities are Applied? What Can I Learn from these?

\section{Method}

In this study, qualitative research method was preferred. The reason why the qualitative research model is preferred is that it is one of the processes of producing information to understand people's lifestyles, stories, behaviours, organizational structures and social change (Strauss \& Corbin, 1990). Qualitative research and qualitative data collection techniques such as observation, interview and document analysis are used and it is possible to define a qualitative process for the realization of perceptions and events in a natural environment (Yıldırım \& Şimşek, 2013). Self-study as a qualitative research designs was used in this study. Self-study not only helps us understand what we do and how we do it, but also how we improve ourselves in practice. Self-study research guides us to better understand the relevant practice, to share our arguments, and to form a living education theory (Hamilton \& Pinnegar, 2006). Self-study is actually a reflective process that enables the practitioner to make sense of the complexities and contradictions experienced during the application process (Austin \& Senese, 2004). Moreover, the practitioner develops classroom practice (LaBoskey, 2004) and adds new knowledge to teaching knowledge (Loughran, 2008). An important component of self-study is to examine one's values and beliefs in practice (Austin \& Senese, 2004; Tidwell \& Fitzgerald, 2004). The reason for choosing a self-study method in my research is to give a new perspective to the belief and values of the teachers. In this way, the teacher can focus on how the beliefs and values alter. Self-Study is a systematic research methodology that examines and develops our professional practices (Hamilton \& Pinnegar, 2004). In the self-study research, the self is a different part of the study and the focus is on our own practice and content (Bullough \& Pinnegar, 2004). The reason for this is to minimize the gap between practice and theory (Hamilton \& Pinnegar, 2004). Traditional qualitative analysis forms are used in the documents 
during the self-study and in their analysis (Schulte, 2009). Self-study uses "I" language. Therefore "I" language was used to describe the data as well in data analysis.

\section{Participants}

A purposeful working group was used in this study. According to Patton (1987), criterion purposeful sampling selection is important in making valid generalizations by providing probability-based sampling representation. The purpose of this selection is to minimize the problems, to participate in the research to be made, to provide easy accessibility of the researcher.

Table 1. Features of Resercher and Participant Teachers

\begin{tabular}{|c|c|c|c|}
\hline Role & Researcher & Moon & Sun \\
\hline Age & 33 & 40 & 36 \\
\hline Bachelor's degree & Science Education Program & $\begin{array}{l}\text { Science Education } \\
\text { Program }\end{array}$ & $\begin{array}{l}\text { Science Education } \\
\text { Program }\end{array}$ \\
\hline Master's degree & Science Education Program & Education Program & - \\
\hline $\begin{array}{l}\text { Seniority } \\
\text { socio-economic status of } \\
\text { the school }\end{array}$ & $\begin{array}{l}8 \text { year } \\
\text { Average-down }\end{array}$ & $\begin{array}{l}16 \text { year } \\
\text { High }\end{array}$ & $\begin{array}{l}8 \text { year } \\
\text { Middle }\end{array}$ \\
\hline Activities & $\begin{array}{l}\text { Rocket, Bridge, Mars } \\
\text { Mission, Code, Robot }\end{array}$ & $\begin{array}{l}\text { Rocket, Bridge, Mars } \\
\text { Mission, Code }\end{array}$ & $\begin{array}{l}\text { Rocket, Bridge, Mars } \\
\text { Mission }\end{array}$ \\
\hline
\end{tabular}

So as to compare my practices with other practitioner teachers and gain different perspectives, I decided to work with two different practitioner teachers in my research. In this context, the research was conducted with one male and one female teacher (See in Table 1), "Moon" is 40 years old, has a master's degree in education programs, has 16 years of experience as a science teacher and works in a school in Çankaya district of Ankara, where there is a high socioeconomic level. "Sun" is 36 years old, has 8 years of experience as a science teacher and works in an area where the socio-economic level is accepted as medium in Keçiören district of Ankara. They were both willing to attend the research process and this contributed to my research in that I could communicate with them easily.

\section{STEM Applications}

In my research lasting for 12 weeks, I have used five STEM applications that I had developed previously. I developed STEM activity papers for my students to gain an understanding of STEM history, and especially to make them see the people who worked or are still working in the field of STEM as role models. I examined the thesis studies on STEM education at home and abroad, but at this point I observed that there was no consensus on which activities can be considered STEM. I prepared the activities with the understanding of transdisciplinary (Trans) STEM, which Vasquez et al., (2013) announced. In this sense, I assumed the engineering applications as the center and linked them with science concepts following the mathematical data collection. Since the tools mentioned in the activities (rocket, bridge, etc.) are technological tools, I did not include programming or coding skills in the course activities. All the activities are hands-on applications. I linked the activities to the achievements in the 2013 MoNE science curriculum. I also referred to various videos of people working in relatively more interesting STEM fields in order to enrich the content with visual elements. I found out that some of the studies in the field of STEM were about gender inequality. Therefore, with a view to balancing the gender factor, I tried to include two male and two female characters at the end of the subjects. Table 2 shows the STEM model, the activity names and STEM characters introduced in the activities. 
Table 2. Fields Related to STEM Activities and STEM People

\begin{tabular}{|c|c|c|c|c|c|c|c|c|c|c|c|}
\hline time & STEM model & $\begin{array}{l}\text { Activity } \\
\text { Name }\end{array}$ & $\begin{array}{l}\text { At the } \\
\text { beginning } \\
\text { of the } \\
\text { subject }\end{array}$ & $\begin{array}{l}\text { Sci } \\
\text { enc } \\
\text { e }\end{array}$ & $\begin{array}{l}\text { Tech } \\
\text { nolog } \\
\text { y }\end{array}$ & $\begin{array}{l}\text { Engi } \\
\text { neeri } \\
\text { ng }\end{array}$ & $\begin{array}{l}\text { Math } \\
\text { emati } \\
\text { cs }\end{array}$ & After STEM Ac & tivities & & \\
\hline $\begin{array}{l}\text { 1st and 2nd } \\
\text { week (4 } \\
\text { lessons) }\end{array}$ & $\begin{array}{l}\text { Trans- } \\
\text { disciplinary }\end{array}$ & Rocket & Newton & $\checkmark$ & $\checkmark$ & $\checkmark$ & $\checkmark$ & $\begin{array}{l}\text { Lagari Hasan } \\
\text { Çelebi }\end{array}$ & $\begin{array}{l}\text { Valentina } \\
\text { Tereşkova }\end{array}$ & $\begin{array}{l}\text { Stephan } \\
\text { Hawking }\end{array}$ & Feryal Özel \\
\hline $\begin{array}{l}\text { 3rd ve 4th } \\
\text { week (4 } \\
\text { lessons) }\end{array}$ & $\begin{array}{l}\text { Trans- } \\
\text { disciplinary }\end{array}$ & Bridge & $\begin{array}{l}\text { Mimar } \\
\text { Sinan }\end{array}$ & $\checkmark$ & $\checkmark$ & $\checkmark$ & $\checkmark$ & $\begin{array}{l}\text { Leonarda } \\
\text { Davinci }\end{array}$ & $\begin{array}{l}\text { Sabiha Rifat } \\
\text { Gürayman }\end{array}$ & El-cezeri & Zaha Hadid \\
\hline $\begin{array}{l}5 \text { th and } 6 \text { th } \\
\text { week }(4 \\
\text { lessons) }\end{array}$ & $\begin{array}{l}\text { Trans- } \\
\text { disciplinary }\end{array}$ & $\begin{array}{l}\text { Mars } \\
\text { mission }\end{array}$ & $\begin{array}{l}\text { Neil } \\
\text { Armstrong }\end{array}$ & $\checkmark$ & $\checkmark$ & $\checkmark$ & $\checkmark$ & Galileo & $\begin{array}{l}\text { Burçin Mutlu } \\
\text { Pakdil }\end{array}$ & Umut Yıldız & Elon Musk \\
\hline $\begin{array}{l}7 \text { th and } 8 \text { th } \\
\text { week }(4 \\
\text { lessons) }\end{array}$ & $\begin{array}{l}\text { Trans- } \\
\text { disciplinary }\end{array}$ & Code & $\begin{array}{l}\text { Thomas } \\
\text { Edison }\end{array}$ & $\checkmark$ & $\checkmark$ & $\checkmark$ & $\checkmark$ & Nicola Tesla & Marie Curie & Mete Atatüre & $\begin{array}{l}\text { Canan } \\
\text { Dağdeviren }\end{array}$ \\
\hline $\begin{array}{l}9 \text { th, 10th, 11th } \\
\text { and 12th } \\
\text { week ( } 8 \\
\text { lessons) }\end{array}$ & $\begin{array}{l}\text { Trans- } \\
\text { disciplinary }\end{array}$ & Robot & Bill Gates & $\checkmark$ & $\checkmark$ & $\checkmark$ & $\checkmark$ & $\begin{array}{l}\text { Mark } \\
\text { Zuckerberg }\end{array}$ & Steve Jobs & $\begin{array}{l}\text { Ada } \\
\text { Lovelace }\end{array}$ & $\begin{array}{l}\text { Ayşegül } \\
\text { İldeniz }\end{array}$ \\
\hline
\end{tabular}

\section{Data Collection Tools}

\section{Interview}

Interviews are purposeful and formal, informal or structured interviews that include open-ended answers, and they are intended to get people's views on specific issues (Bogdan \& Biklen, 2006). Interview is frequently used in research of self-study nature. Some researchers conduct in-depth interviews for life history information (Smith, 2005), and others carry out these to obtain personal information and beliefs of individuals (Yerrick \& Hoving, 2003). In my self-study, interviews were conducted with students and teachers using a semi-structured interview form. Validity of interview ensured by two experts in science education. Interview questions were prepared by the researcher in accordance with expert opinions. Interview questions were;

What do you think science is?

Does the science course meet the students' expectations?

How do you evaluate the integration of science-technology-engineering-mathematics?

Does STEM understanding contribute to the development of our country?

Do you use the history of science in your lessons?

Could you tell us about the study you conducted?

How do you think we can tell the history of science or scientists?

How did we use technology?

How did you design and resort to group work in STEM activities?

What did you as a teacher discover about yourself? curriculum?

It is speculated that there will be a STEM-based curriculum. Do you have any suggestions for this STEM

\section{Life Story}

In order to make a change in our students, we need to listen to the voice within us, which gives us the power to critically evaluate and confront a situation (LaBoskey, 2004). One has to think about himself, what he has experienced, has to examine the results he has drawn from them and also their reflections on life, giving an answer to the questions: "Who am I?" "Where am I going?" (LaBoskey, 2004). The self-study begins with "I'. Obviously, an important point of self-study research is the "self" (Bullough \& Pinnegar, 2004). Autobiography allows us to explore our experiences and ourselves (Ellis, 2004). In this study, I put forward the life stories and experiences of researchers and practitioners, and their teaching experiences and perspectives on the teaching-learning process in science and STEM education. Life stories in 
self-study enabled me to understand the teaching experiences of myself and the participating teachers while helping with the understanding of in-and-out factors of beliefs. Observations

Evertson and Green (1986) describe observation as monitoring of the educational process. Observation is a factual process that is recorded in the field of research by means of the researcher's five senses, usually with a tool and for scientific purposes (Angrosino, 2007). According to Marshall and Rossman (2006), one of the most important techniques in qualitative research is observation. Non-verbal behavior, natural environment and time-based analysis are the strengths of observation (Bailey, 1982). During self-study class practices, photographs can be taken to answer the questions and to create stories about the person's life, and some points can be emphasized (Mitchell, Weber \& Pithouse, 2009). Video recordings play an important role in observing the classroom environment in practice and theory (Hamilton \& Pinnegar, 2006). Bencze et al., (2003); Barnett (2006); Yung, Wong, Cheng, Hui and Hodson (2007) emphasize that the use of videos in teacher-training is an important tool for the professional development of teachers. As a result, the use of video can be a valuable tool for teachers and researchers in learning to teach science (Martin \& Siny, 2012). In my study, I used video recording and photographs for observational purposes, and this contributed to my study both in terms of self-study and understanding of my practices in the classroom through the eyes of the students. Life stories in self-study enabled me to understand the teaching experiences of myself and the participating teachers while gaining insights into in-and-out factors of values.

\section{Data Collection Process}

The research process started with the interview with the participating teachers. Then, application forms were given to the teachers about STEM activities. After the activities, reinterviews were held with the teachers. Recordings of the interviews with teachers were collected by a voice recorder. It was then analyzed by the researcher. The interviews lasted approximately 30 minutes. The course processes of the participating teachers were recorded with a video camera.

\section{Data Analysis and Interpretation}

In my research, I used narrative and content analysis techniques to analyze the data. When narrative is taken as a method, it starts with the stories that individuals tell and with their experiences (Creswell, 2013). Riesmann (2008) describes narrative analysis as "a family of methods for interpreting texts that are similarly narrated". Czarniawska (2004) defines narrative research as a special form of qualitative research design, which are narrative texts or speeches about an event or events that have a chronological relationship with each other. Life stories cannot be clarified in a simple way, in fact they need to be analyzed separately and thoughts need to be recognized. (Holt-Reynolds \& Johnson, 2002). Otherwise, if the experiences are misunderstood or insufficient, the probability of making mistakes increases. Denzin (1998) recommends that a researcher identify a series of objective experiences in the subject's life and begin biographical analysis. The researcher usually searches the database (interviews or documents) for concrete contextual biographical materials. During the interview, the researcher should encourage the participant to open up various parts of the stories and ask the interviewee to theorize his life. These theories may be related to career models, life processes, social world models, relational biography models and natural history models of life. The researcher should then restructure the biography of the individual from the narrative sections and identify the factors that shape the researcher's life.

a) Processes in the life of the individual, 
b) Different theories of life experiences,

c)Situations that emphasize the general and specific characteristics of life that lead to an analytical abstraction (Creswell, 2013).

According to Pinnegar (1998), self-study researchers carefully observe the environment, collect data carefully and record observations; works on research with other methods to uncover intuitions in current practice, examines the contribution of the life story for the environment, and reflects on the results by intersecting these data to understand initiatives. The data collected in my study were analyzed by content analysis in order to define the opinions of the participants in depth (Stemler, 2001). According to Bogdan and Biklen (2007), content analysis is an objective and systematic examination of verbal, written and other materials and organizing them according to certain themes. Content analysis is to bring together similar data within the framework of certain concepts and themes and interpret them in a way that the reader can understand. Content analysis is used in the processing of qualitative research data. This process consists of four stages; data coding, finding themes, arranging codes and themes, and defining and interpreting the findings (Yıldırım \& Şimşek, 2013, s. 40). I used narrative in analysing my life stories in self-study. I made use of content analysis techniques to analyze the interview in self-study. Lastly, I used classroom observations (Video Recordings and Photos) to detect what teachers do in-class.

\section{Results and Discussion}

\section{a) What are my values and beliefs as a science teacher? How do these values and beliefs become apparent in the classroom where I use the STEM applications?}

In this section, you can see the excerpts obtained from the interview which was carried out with science teachers before the STEM applications in order to determine their values and beliefs. I knew that science was not a one-dimensional concept. The whole was something different than all the parts that made it up. Whatever the success in education means today and whatever our values are for this success, there has to be many factors for the formation of science and scientific knowledge. While reading my teacher story, I noticed that there were some people that I followed at every level. My middle school math teacher was highly influential on me. While reading the textbooks, I could see that there was a lack of emotion. We read hundreds of books in our lives. But a few of them leaves their effect on us. I thought that the textbooks should have a permanent effect on the students. If we are to talk about science, the journey of science has to be explained very well. This could be done through the mentioning of relevant humans and the contexts that produce the best science. The time period, processes, emotions, thoughts, possibilities and impossibilities have to be given in the course content. Why was not there any link between the role model and these scientists? Scientists worked hard to develop scientific knowledge. Lovosuier said while going to the execution table to his friend; "Look at my eyes after my head fell, if my eyes can still blink, even after death, the brain can continue its conscious movements,". I don't know whether it was real or not, but I believed that people who contributed to science, technology, engineering, mathematics can be role models for the development of societies. On the other hand, I wanted to design my lessons with what I learned during in-service activities. Yet the program to be taught, gains, time, paperwork always constituted constraints. This made me realize that I could not do exactly what I wanted to do. I thought that a science practice course would be a good opportunity. Okay, it might be more time consuming, but the students coming to this class were already those who selected this course. I thought they had an interest in science. 36 students had chosen the science applications course at that time. So, I thought that the class profile, the possibilities, and so on 
provided me with an opportunity to implement STEM activities. However, in the activities I watched on the internet resources, the students were listening to the teacher carefully and actively participating in the activities. Was that the effect of the camera? Or were there any other cultural factors? I taught classes from the first grade to the university students. As the age group grew, I could see that the appearance of the factors such as concentrating on the lectures and level of participation increased. Nevertheless, this was not very much true for secondary school students. When watching the foreign sources (like videos), I was not interested in what the teacher did, but what the student did. They were discussing, trying, measuring things, and working together. My expectation was that this would be more effective with the students who were high achievers in the class. On the other hand, determining what the students would do in the future was another consideration for me. After all, they were not an inanimate object, a machine or a tool, and, it was relentless to direct their future in line with our needs. On top of these there were many graduates of teaching departments and who wanted to teach today but could not become a teacher because there was no effective policy of the state for this. These people are trained for years, perhaps wasted energy, money, etc. in an area where they would perhaps never be able to work. In this respect, both the country and the society are in a disadvantageous position. With these thoughts, I designated STEM events. I was excited to start the class, but at the same time I was worried about as to whether everything would be ruined or not.

Table 3. My Values and Beliefs Before the STEM Applications

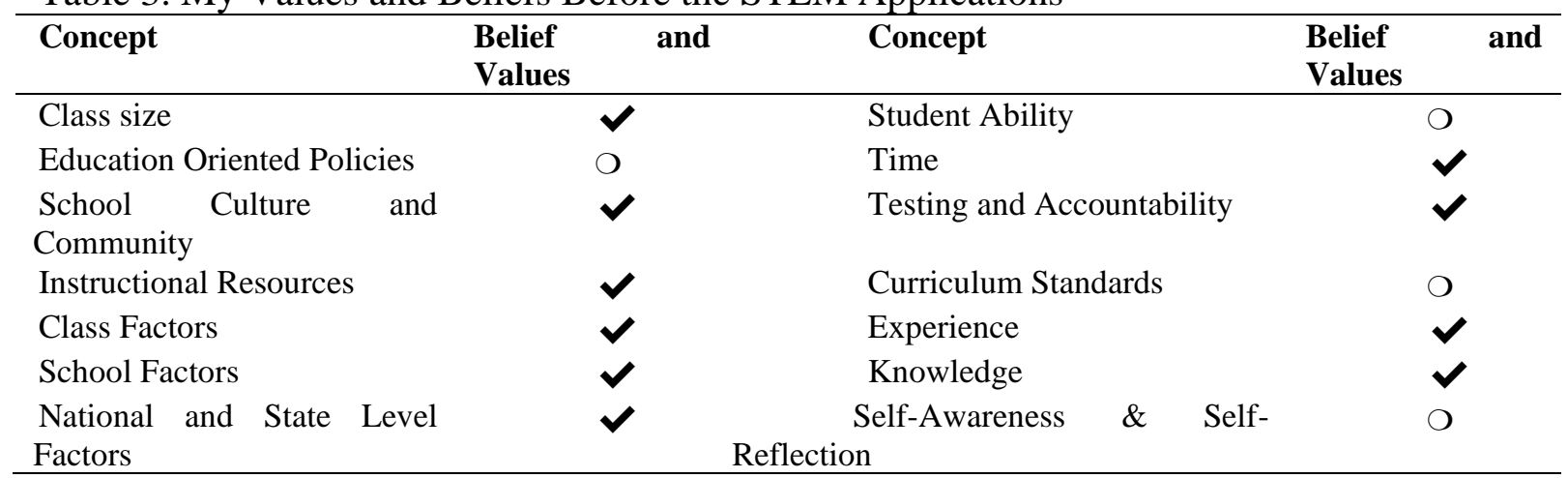

$\checkmark=$ I have Belief $\boldsymbol{X}=\mathrm{I}$ have no belief $\mathrm{O}=$ Undecided

In Table 3, I listed my values and beliefs prior to the practice. There was a strong link between my beliefs about STEM activities and my practice. I was able to see my values and beliefs more clearly before the research with the help of the concepts proposed by Buehl and Beck (2015). I was indecisive about education policies. Although I did not conduct a study on educational policies within the scope of my research, I owned some ideas about the reflection of the course contents in the suggestions section. In addition to that, the training program did not match $100 \%$ with the content and concepts I prepared. I was not sure about the student skills. They could give up saying "I can't do that" or "I'm bored.". Another dimension was that I was not confident in myself thinking that I may not express myself as desired during the study. Though self-study was a good opportunity for the practitioner to recognize himself, what we have in mind is not always what we express. On the other hand, I had full faith in class size, type of school and society, teaching resources, class factor, school factor, regional / national and state factor, student ability, time, testing and accountability, experience and knowledge. 
Table 4. My Values and Beliefs After the STEM Applications

\begin{tabular}{|c|c|c|c|}
\hline Concept & $\begin{array}{l}\text { Belief } \\
\text { Values }\end{array}$ & Concept & $\begin{array}{l}\text { Belief } \\
\text { Values }\end{array}$ \\
\hline Class size & $\checkmark$ & Student Ability & $\checkmark$ \\
\hline Education Oriented Policies & O & Time & $\checkmark$ \\
\hline $\begin{array}{l}\text { School Culture and } \\
\text { Community }\end{array}$ & $\checkmark$ & Testing and Accountability & $\checkmark$ \\
\hline Instructional Resources & $\checkmark$ & Curriculum Standards & O \\
\hline Class Factors & $\checkmark$ & Experience & $\checkmark$ \\
\hline School Factors & $\checkmark$ & Knowledge & $\checkmark$ \\
\hline $\begin{array}{l}\text { National and State Level } \\
\text { Factors }\end{array}$ & $\checkmark$ & $\begin{array}{l}\text { Self-Awareness } \\
\text { on }\end{array}$ & $\checkmark$ \\
\hline
\end{tabular}

$\checkmark=\mathrm{I}$ have Belief $\boldsymbol{X}=\mathrm{I}$ have no belief $\mathrm{O}=$ Undecided

Following the practice, I found that the connection between my beliefs about STEM activities and my practice gained strength over time. As in Table 4, with the help of the concepts by Buehl and Beck (2015), I could see more clearly the values and beliefs that I had before the research compared with my practices. I remained indecisive about education policies, which was one of these external factors. Since my indecisiveness was about one of the external factors, I could not intervene directly. In addition, the training program did not correspond $100 \%$ with the content and concepts I had prepared, which showed that the previous year's content was not fully understood by the students. I also witnessed misconceptions in some concepts such as mass-weight and velocity-speed. At first, I was not sure about the students' talents. However, almost all students participated in the activities carried out. Yet I observed that some students were not fully aware of the necessity of the application and the study during STEM applications. Similarly, I was not sure if I could express myself as much as I wished to do so throughout the study. But when I started to write my observations and thoughts, I had the opportunity to better understand both myself and my students. I also observed that I was right in my thoughts about the class size, school type and society, teaching resources, class factor, school factor, regional / national and state factor, student ability, time, testing and accountability, experience and knowledge.

b) Findings about the sub-problem: How does the Values and Beliefs of Participant Science Teachers Coded 'Moon', are revealed in the classes where Science, Technology, Engineering and Mathematics (STEM) Activities Are Applied, What Can I Learn from These?

In this section, we see excerpts from the interview conducted to determine the values and beliefs of the science teacher coded "Moon".

Me: What do you think science is?

Moon: I think science means changing, wondering means and questioning. If you want to change things, you need to apply science. Science means change and development. It means up-to-dateness, query and scanning; I think that's what science means.

Me: Well, considering our educational programs, do you think science meets the need in practice and theory?

Moon: We have programmed the training programs from 1 to 12 very well. We have built a spiral curriculum. There's a disconnect starting from the bottom. However, we cannot see those curricula being actually applied.

Me: Why do you think so?

Moon: The program is very nice, but missing information at any level affects the problems above. They are being applied, but it is not working.

Me: Does the science course meet the students' expectations? 
Moon: Curriculum is constantly changing. The previous curriculum was not spiral. The subjects changed over time. But I think it meets expectations.

Me: Which courses do you think are closest to science?

Moon: In my opinion, it is mathematics and it can also be social studies in terms of methodology.

Me: I don't know if you've reviewed the new draft program. It writes engineering will also be included in science education. It writes that gaining understanding of the subject area of science-engineering-technology and mathematics (STEM) will be ensured. What do you think about it?

Moon: Teachers must go through in-service training. We may not catch up with that understanding, for example, the youngest teacher in this school has 10 years of experience. So, when you say, "apply this in your classes", you cannot obtain anything.

Me: Does STEM understanding contribute to the development of our country?

Moon: It remains at the theoretical level in the secondary school curriculum. It lags behind in application and practice. I think the studies provide very theoretical academic information. If training is given about the kitchen of the business, it will be more efficient or if there is practical information with which we can find solutions in our daily life such as business technical-home economy like in the previous years.

Me: Do you use the history of science in your lessons?

Moon: We usually talk about the lives of salient scientists. However, what must be revisited is conveying what kind of difficulties hindered the understanding of science in that specific period and what was done for the advancement of science. We need to differentiate between the scientific understanding of that time and today's understanding of science.

Me: Do you think scientists can draw the attention of students? Do the students take scientists as a role model?

Moon: I don't think so. Because the teacher is not a singer or a footballer. I think making a name is not important, in fact the history of science or the way of science should be taught.

Table 5. Moon's Values and Beliefs Before the STEM Applications

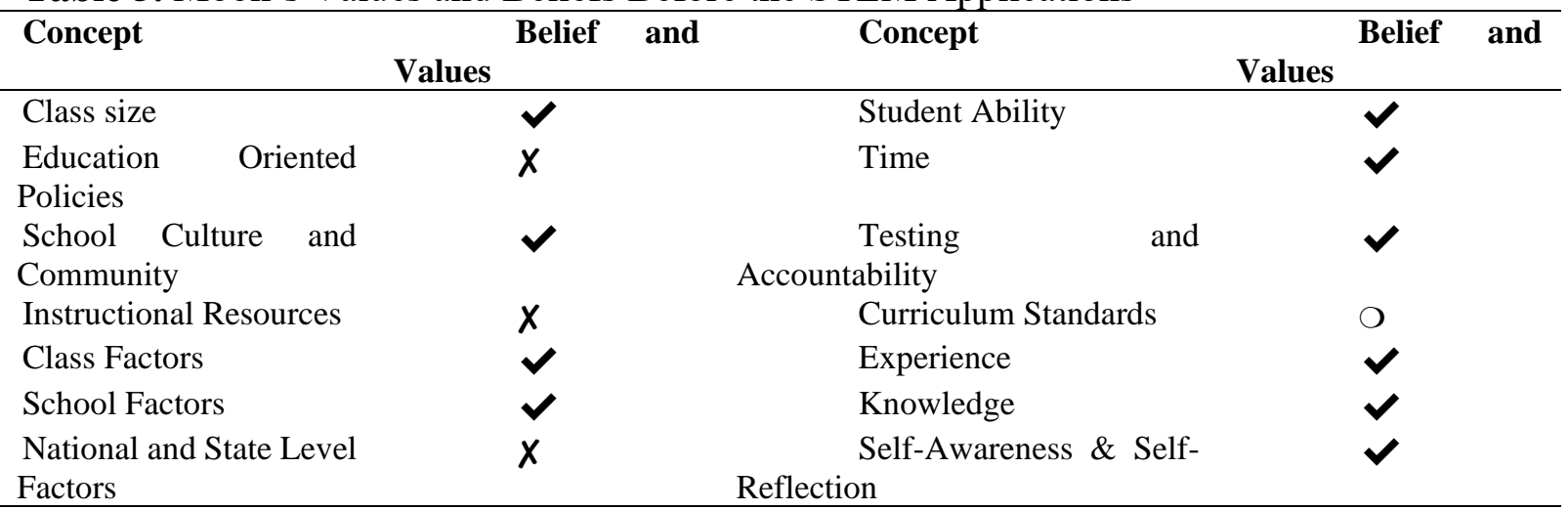

$=\mathrm{I}$ have Belief $\boldsymbol{X}=\mathrm{I}$ have no belief $\mathrm{O}=$ Undecided

In Table 5, within the framework of Buehl and Beck (2015), I tried to interpret the views of the teacher "Moon" before the STEM activities. Firstly, it can be said that the considerations in class size, class factor, time, student ability to participate in the application are complete. Approximately 15 years of teaching experience shows that it is important for a teacher to have the knowledge and experience of the subject and the values and beliefs. In my interview, however, the external factors such as teaching resources and policies gained importance too.

In this section, we see the excerpts from the interview conducted to determine the values and 
beliefs of the science teacher coded "Moon'.

Me: Could you tell us about the studies you conducted?

Moon: I have to take over a 6 hour-class in return for my salary because I am working as vice principal. For this reason, I refrain from choosing the main course of science, I am an administrator, there can be some disruptions during the term. That's why I usually try to get into intelligence games and science applications. I usually focus on group activities in the games of intelligence class. My goal is to make students get a taste for socialization, quick thinking and competition. In the course of science applications, I had the opportunity to concentrate on my studies according to the fields and discipline of STEM which has been applied intensively in recent years.

Me: How do you think we can describe the history of science or the scientists?

Moon: Let us imagine a river, say that it has never existed before and then it starts to flow from its spring. From this spring, the water will find its own way, on which it will develop the molecules important to life such as minerals, vitamins, nutrients and so on. How beneficial this river can become for the environment or humanity depends on it gaining the correct amount of all the necessary components and also on its carrying the sufficient level of these molecules and finally on the extent to which the water is potable. The drinkers are the scientists. Every drinker should also add something to the value of the water so that the others will get the benefit of it in the future. Here not only humans but also, plants, animals, the nature, the human history and culture come into play. Today's scientists must follow the universal values and be up-todate and work solely for the positive progress of every living thing and being in the universe. An objective judgment or opinion should be created. In particular, some areas should not be left to the monopoly of certain countries or schools e.g. Space Research: NASA. All scientists working in a university or for an institute should do their best in their field.

Me: Considering the activities we do, which of the fields of science, technology, engineering and mathematics do you think we made use of?

Moon: We resorted to every field. For example, Science was referred to in the Mars mission event; Astronomy: technology, space technology, spacecraft; Engineering: Spacecraft design and its drawing, creation and use of this design in the outside world with the materials available; Mathematics: making measurements for the appropriate height needed for landing and making some measurements for these heights when they need to be changed in other testings.

Me: How did you manage group work in STEM activities? Did each student participate?

Moon: STEM Activities group work was formed heterogeneously by taking into consideration the conditions of each study and the readiness and maturation levels of the students whose general academic and social skills I know. Students participated. A complete group work was done with the necessary guidance and with the warnings given when some of the students who wanted to work individually and who were more productive in this way rarely wished to leave their group.

Me: What do you think STEM activities brought to the students?

Moon: They recognized that especially the concepts that they thought they were not familiar with such as environment, vehicles, etc. could actually be easily understood by themselves. They understood that they were able to do something. STEM is an activity that appears to be difficult and complex. It brings many events occurring in the outside world into the classroom, proportional to the student's overall education and training capacity. The students got the chance of experiencing the similar environments to those where the people leading the science were living in. And, they reached the conclusion that the scientists might have made their studies under more difficult conditions than they themselves experienced. It was very good for the students to see that the people who were similar to them set a goal and achieved it later. 
Me: It is speculated that there would be a STEM-based curriculum. Do you have any suggestions for the STEM curriculum?

Moon: An in-service training can be provided to teachers on these subjects. Postgraduate education can be given to graduates of science and education. In addition, integration studies required for this transition can be added in the course syllabus. In the global world, STEM studies will inevitably enter into the training programs. In order not to be caught unprepared for this issue, we-teachers-should start the studies in advance.

Me: What have you discovered as a teacher about yourself?

Moon: As a teacher, I always say that the students do their best when they are allowed. The Equal Opportunity Principal is also counted as the basic principle of education in the National Education Law No. 1739. What I discovered about myself is that I took the students into space and sent a spacecraft to Earth from there. I did this mentally. This time, the students did not ask whether the pasta should be sauced, but instead they asked me how many more they needed to put on top of it if they wanted it to be more durable. I trained little scientists. I'm a science teacher. I have not discovered newly in the field of science, but I am satisfied now. I care about this STEM and want it to be included in the training programs in the future.

Table 6. Moon's Values and Beliefs After the STEM Applications

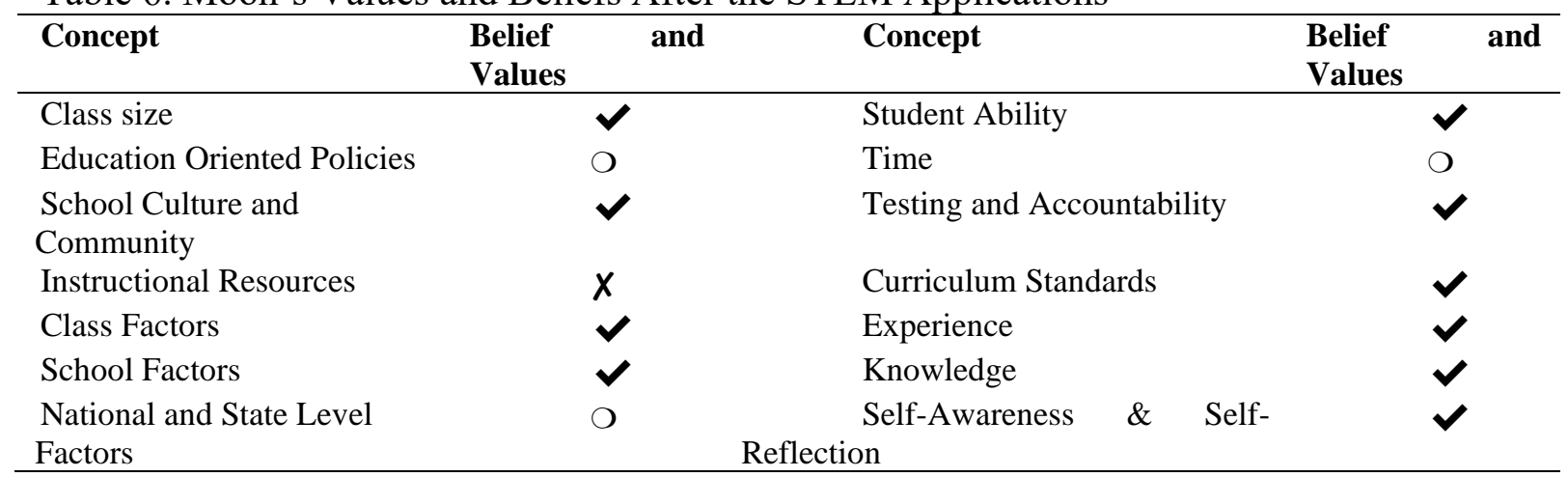

$=$ I have Belief $\boldsymbol{X}=\mathrm{I}$ have no belief $\mathrm{O}=$ Undecided

Table 6. I tried to match the answers of the teacher within the dimensions provided by Beuhl and Beck (2015). Moon was working at a place with a high socio-economic level. The number of students in the classroom was low., I observed that there are applications within the dimensions of class size, type of school, teaching resources, class factor, school factor, student ability, experience and knowledge. However, Moon did not mention about education policies, state and national factors and time factor.

(c) Findings about the sub-problem: How do The Values and Beliefs of the Participatory Science Teachers coded "Sun" are revealed in the Classes where Science, Technology, Engineering and Mathematics (STEM) Activities are Applied? What Can I Learn From these?

In this section, you can see the excerpts from the interview carried out to determine the values and beliefs of the science teacher coded "Sun" before the application.

Me: What do you think science is?

Sun: It is the ability to present an observable or demonstrable hypothesis with concrete evidence.

Me: Does the science course meet the students' expectations? 
Sun: Partially yes. Issues were reduced to a more accessible level and some restrictions were also introduced. We teach at a simpler level, but when I am trying to answer the students' question of "why?", I feel the lack of information removed from the curriculum and I have some trouble.

Me: How do you evaluate the integration of science-technology-engineeringmathematics?

Sun: These are the concepts that constantly interact with each other and constantly feed each other.

Me: Does STEM understanding contribute to the development of our country?

Sun: The integration of science, technology, engineering and mathematics is one of the factors affecting the development of a country. The integration of science, technology, engineering and mathematics of a country is directly related to the development of that country. In the countries not having these four, heavy industry and production industry cannot be expected to develop. In parallel to this, it is not possible to create new jobs. The service sector is not included in it.

Me: Do you use the history of science in your lessons?

Sun: I don't use the history of science in my classes. I used to talk about Newton, Mendelev and Archimet in the past. There was an interest because the event and the relevant people were told altogether (the apple fall or the float in the tub). I think my goal in explaining the history of science was to give the students a sense of curiosity about scientists. This year we covered the history of the periodic table in the lesson. I tried so hard to motivate the students.

Table 7. Sun's Values and Beliefs Before the STEM Applications

\begin{tabular}{|c|c|c|c|}
\hline Concept & Belief and Values & Concept & Belief and Values \\
\hline Class size & $\mathrm{O}$ & Student Ability & $\checkmark$ \\
\hline Education Oriented Policies & $\mathrm{O}$ & Time & $\checkmark$ \\
\hline School Culture and Community & $\mathrm{O}$ & Testing and Accountability & $\checkmark$ \\
\hline Instructional Resources & $\checkmark$ & Curriculum Standards & $\mathrm{O}$ \\
\hline Class Factors & O & Experience & $\checkmark$ \\
\hline School Factors & $\mathrm{O}$ & Knowledge & $\checkmark$ \\
\hline National and State Level & $\mathrm{O}$ & Self-Awareness \& Self-Reflection & $\checkmark$ \\
\hline
\end{tabular}

Factors

$\boldsymbol{V}=\mathrm{I}$ have Belief $\boldsymbol{X}=\mathrm{I}$ have no belief $\mathrm{O}=$ Undecided

In Table 7, I tried to interpret the views of "Sun" teacher before the STEM activities within the framework stated by Buehl and Beck (2015). "Sun" teacher had enough knowledge and skills for the science courses. Sun's willingness to participate in the study and belief in working on time and student ability were complete. Sun was convinced that Sun would contribute to selfawareness and self-reflection. However, Sun did not mention about the external factors such as education policy and state factor. Sun did not express positive or negative views in these areas.

In this section, you can see the excerpts from the interview carried out to determine the values and beliefs of the science teacher coded "Sun".

The curriculum changed in 2012-2015 and 2016. Finally, the curriculum of the 8th grade was changed in 2016. I follow the program in terms of the learning outcome and the subjects. Me: Could you tell us about the study you conducted?

Sun: We had fun during the activities. In the first activity I did a demonstration experiment. I saw that the activities attracted the attention of the students. In the following week, the students came to me and asked what they would do. I formed the student groups for the Bridge and Mars mission activities. They conducted the activities on their own and I 
rewarded the successful groups with chocolate. There were scientists at the beginning and at the end of the activities. Obviously, I did not have the detailed knowledge of the history of science and scientists. As I said before, I'm not interested in it. But we read the content and watched the videos with the students together.

Me: How do you think we can tell the history of science or scientists?

Sun: Archimedes' coming out of the bathtub or Newton's apple falling in the head are interesting events. I think the curiosity about the work should be highlighted rather than the person himself. What should be the focus is the stimulating effect, namely the event that person experienced. The question should be: What was the reason why this man tried hard to work in this field?

Me: Considering our activities, which of the STEM areas do you think we used?

Sun: I think we have used all of science-technology-engineering and mathematics.

Me: How did we use technology?

Sun: It depends on what we understand from the concept of technology, for example, we made rockets at the rocket activity and talked about the rockets, which was a technological concept.

Me: Do you think it should certainly be electronic? For example, is a table also a technological tool?

Sun: Aa table is not, I think it should be electronic.

Me: How did you apply group work in STEM activities?

Sun: I tried to make homogeneous groups, but they moved to the groups that they could work in the other weeks. Each group worked, but some students in the group were reluctant. I think these students have little interest in science. In addition, my class was crowded, and the number of students negatively affected my activity.

Me: What do you think STEM activities brought to the students?

Sun: Applicability. What these activities brought is that the students could see that they are learning things and they could also apply what they learned.

Me: What did you as a teacher discover about yourself?

Sun: The teacher should tell the subject, give certain concepts and definitions, complete the unit and then there should be an application of what the students have learned. STEM is a production-oriented activity. But the time is troublesome, that is, there must be more time for it.

Me: It is speculated that there will be a STEM-based curriculum. Do you have any suggestions for the STEM curriculum?

Sun: I think STEM will contribute to the students in terms of the activities. I think that training in this field should be provided for the teachers, and it should be voluntary. There may be a sketchy book like a guidebook, but it may limit the teachers in terms of its applicability.

In Table 8, I tried to interpret the views of "Sun" teacher after the STEM activities within the framework stated by Buehl and Beck (2015). "Sun" teacher gave a lot of information about the content used in the STEM activities. 
Table 8. Sun's Values and Beliefs After the STEM Applications

\begin{tabular}{|c|c|c|c|c|}
\hline Concept & Belief and Values & Concept & & Belief and Values \\
\hline Class size & $x$ & Student Ability & & $\checkmark$ \\
\hline Education Oriented Policies & O & Time & & $x$ \\
\hline $\begin{array}{l}\text { School Culture and } \\
\text { Community }\end{array}$ & O & Testing and Accountability & & O \\
\hline Instructional Resources & $\checkmark$ & Curriculum Standards & & $\checkmark$ \\
\hline Class Factors & $\checkmark$ & Experience & & $\checkmark$ \\
\hline School Factors & $\mathrm{O}$ & Knowledge & & $\mathrm{O}$ \\
\hline $\begin{array}{l}\text { National and State Level } \\
\text { Factors }\end{array}$ & O & $\begin{array}{l}\text { Self-Awareness \& } \\
\text { Reflection }\end{array}$ & Self- & $\checkmark$ \\
\hline
\end{tabular}

$\boldsymbol{V}=\mathrm{I}$ have Belief $\boldsymbol{X}=\mathrm{I}$ have no belief $\mathrm{O}=$ Undecided

Moreover, as I understand from Sun's practices, Sun stated that activities developed a sense of curiosity in students, avoided memorization, but were influenced by external factors due to the examination systems. An experience of 10 years meant possessing deep knowledge of course contents. Sun stated that practices suffered from time and class size. "Sun" teacher did not talk much about the external factors, so I could not make a comment on whether the education policies were effective at school and at a national level or not. Looking at the values and beliefs of the participating science teachers in the classes where science, technology, engineering and mathematics (STEM) activities were applied, I observe Socio-economic and environmental factors are effective in teachers' choice of profession. STEM activities can be implemented more easily in schools with high socio-economic status. There are difficulties in the implementation of STEM activities in crowded classrooms. Teachers' values and beliefs affect their STEM practices. Seeing the practices of other teachers has given me a different perspective about the teaching process that I use.

\section{Conclusion}

Brown and Cooney (1982) and Pejeres (1992) emphasized that values and beliefs are directly proportional to the teacher's actions. Notwithstanding these definitions can be seen as the reflections of the prevailing behavioral theory which was created at that time. The research shows that there are many factors that affect teachers' values and beliefs (Savaşçı \& Berlin, 2012). However, these beliefs and values of the teachers are expressed as an integral structure by Buehl and Beck (2015). In this context, I had the chance to make sense of my own beliefs, values and practices. Buehl and Beck (2015) classified beliefs, values and practices as internal and external factors. Uzuntiryaki, Boz and Kirbulut (2010) stated that one of the internal factors which affect the teachers' practices was their number of the students. During the STEM applications, I worked with a class of 18 students. I found that a class of this number is suitable for STEM applications. However, I understood that working with a classroom of 30 students had negative effects on the classroom management of "Sun" teacher. Education policy was an external factor, and it supported what I wanted to do. As it is expressed both in our country's 2023 targets and in TUSIAD and Turkey STEM reports, it supported the development of production-oriented individuals who make plans, ask questions and work in collaboration. The fact that I conducted my research at my own school and that all the parents gave consent to my work eliminated the obstacles to my practice. I started to develop teaching resources a year ago. However, it was also an advantage for me to do my activities with simple materials. The fact that my class was a science applications class gave me the opportunity to come up with a flexible plan in my study. Also, my students' willingness to attend the elective course of science applications was another advantage. Management, parental support, colleagues and the resources available in a school can support or hinder the relationship between teachers' beliefs 
and practices (Southerland, Gallard \& Callihan, 2011). I did not have any problems in my practices in terms of school factor, administration and environment. At first, I was not sure about the students' abilities. In particular, the teachers' beliefs about the development of students' abilities and motivations affect their practice (Mouza, 2009; Turner, Warzon \& Christensen, 2011). But when the process was over, I was sure about my students' abilities. Examples of external factors include solid accountability, time-effectiveness culture, compulsory curriculum, and state and national assessments (Bryan, 2012). My initial ideas changed over time. I observed that it took more time to implement STEM activities, to talk about scientific knowledge, and to discuss them in depth. I believe that I have conducted a completely transparent process with participating teachers, participating students, my colleagues at the same time bearing in mind other elements that make up the school. The standards of the training program were not at the level I expected, but it was good for my science practice curriculum to provide a flexible study for me. My belief in my experience and knowledge did not change in the process, but I also gained different perspectives when working with my students. I think that I could reflect what I had in my mind into my lessons during this journey which I started in order to understand myself and my practice in the process. As a result, my values and beliefs in STEM activities greatly affected my practices. In this respect, as Laplante (1997) and Bryan (2012) stated, my practices, values and beliefs were influenced by STEM activities. A research-questioning approach about the effectiveness of belief which was conducted by Wilkins (2008) and which included an American elementary school teacher revealed that beliefs are the most powerful direct predictor of research-questioning approach. Since STEM education is also a new approach, it can be examined how the values and beliefs of the teachers giving the STEM education lead their practices. Savaşc1 and Berlin (2012) stated that the more the students' ages are, the more easily the teachers could apply the constructivist practices. Similar expressions can be used within the STEM applications. STEM applications provide high-level of thinking skills. Therefore, it can be thought that teachers who have no difficulty in improving the skills of their students have no problems in the STEM applications. Savaşc1 and Berlin, (2012) point out that the constructivist-oriented secondary school teachers were reluctant to do group work because of potential misbehavior of the students. In my practice, I also encountered some problems among the members of the groups but overcame these by talking to the students and convinced them to work together. It is necessary for teachers to focus on the group work before STEM applications. "Sun" emphasized that he had chosen teaching through various environmental factors. Sun preferred teaching in order to stay where lived, and preferred teaching mathematics, which was popular at that time. Sun had some experience in teaching and worked in different places. But I observed that Sun used traditional methods in the classroom. Sun had been working with 8th grade students for 3 years, so Sun was teaching in accordance with the expectations related to national high stakes exams. Sun had never received in-service training on STEM application before. It was the first time that Sun would use STEM in class. Sun was familiar with the scientists in the curriculum of the 8th grades. But Sun thought these characters were the elements only to be memorized. At first, I thought that he was more knowledgeable about the application. However, I observed that Sun was more protective in practices considering that students would be harmed. Sun also gave small motivating rewards to the students. At the end of the activities, I saw that Sun had followed the programs through the textbooks. Sun also told me that I had to find more interesting facts about the history of science while teaching. STEM activities were practical in terms of its applicability in the class. However, Sun said that class was crowded, so there was a loss of control and some students were reluctant to take part in the activities. Sun was also concerned about time like me. When I compared Table 5 to Table 6 , I found that the values and beliefs in the size, class factor, time, testing, and the standards of education programs did not match with the practices. When I read the story of Moon, I learned that, Moon started to work 
immediately because of the socio-economic status of own family. Moon had a successful school life, and in time Moon moved from science education to administration. In the preimplementation process, Moon complained about the external factors and about the continuous change of the curricula. Moon did not receive an in-service training on STEM, but Moon believed that practical studies would contribute to the students. Moon was working in an environment of high socio-economic status when implementing STEM activities. Therefore, Moon gave me different perspectives in implementing the activities. Moon believed that the history of science should be explained to the students. Moon applied activities in detail, made measurements and, moreover, described practices very well. Moon thought that there would not be any problems with time and with the classroom or the size of the school. At the end of the activity, my testimony showed that Moon was satisfied with the teaching resources available. Moon did not mention about the time factor. However, I understood from Moon's expression that it was positive in terms of the number of the students and the activities. Moon's knowledge and experience in this field was great. I observed that the values and beliefs of the Moon teacher overlapped with practices. As a result, I saw that internal and external factors affected the teachers' values and beliefs, which led to different practices among teachers. "Sun" teacher had used more traditional methods, but I realized that Sun's knowledge was greater in science education. In addition, the number of the students was high. It is difficult to implement STEM activities in crowded classrooms. Moon teacher was spending more time at school, both as an administrator and as a teacher. When Moon needed more materials at the bridge event, Moon got them again, went back and continued the practice. I understood that Moon teacher was a humanist teacher. The activities could be easily implemented with a small group in the schools of a high socio-economic level. STEM activities are more effective in schools with socio-economic environment.

As a result of this research, I found that both the internal and external factors were effective in the implementation of the STEM activities. Enhancing STEM experiences of teachers will help strengthen STEM trainings. Although STEM skills are strengthened, it is important to strengthen external factors. The internal factors such as the teacher's experience and field expertise affect their practices in the classroom. In addition, it was concluded that crowded classes and the change in the socio-economic levels also affect in-class practices. In further researches, the factors which affect the STEM applications of these teachers can be examined in many different dimensions.

\section{References}

Anagün, Ş, Yalçınoğlu, P, Ersoy, A. (2012). An investigation of primary school teachers' beliefs on teaching-learning processes in science and technology course in terms of constructivism. Journal of Theoretical Educational Science, 5 (1), 1-16.

Angrosino, M. (2007). Doing ethnographic and observational research. Thousand Oaks, CA: Sage

Austin, T. \& Senese, J. C. (2004). Self-study in school teaching: teachers' perspective. In J. Loughran, M. L. Hamilton, V. LaBoskey \& T. Russell (Eds.), International handbook of self-study of teaching and teacher education practices. (pp. 1231-1258). Dordrecht: Kluwer.

Bailey, K. D. (1982). Methods of social research. New York: The Free

Bencze, L., Hewitt, J., Pedretti, E., Yoon, S., Perris, K., \& van Oostveen, R. (2003). Sciencespecialist student-teachers consider promoting technological design projects: Contributions of multi-media case methods. Research in Science Education, 33, 163187. 
Brown, C. A., \& Cooney, T. J. (1982). Research on teacher education: A philosophical orientation. Journal of Research and Development in Education, 75(4), 13-18.

Brown, G. T. L., Harris, L. R., \& Harnett, J. (2012). Teacher beliefs about feedback within an assessment for learning environment: Endorsement of improved learning over student well-being. Teaching and Teacher Education: An International Journal of Research and Studies, 28(7), 968-978. doi:10.1016/j.tate.2012.05.003

Bryan, L. A. (2012). Research on Science Teacher Beliefs. B.J. Fraser et al. (eds.), Second International Handbook of Science Education, Springer International Handbooks of Education 24, DOI 10.1007/978-1-4020-9041-7_33

Bogdan, R.C. \& Biklen, S.K. (2006). Qualitative research for education (5th ed). Boston: Pearson Education, Inc.

Buehl, M. M., \& Beck, J. (2015). The relationship between teachers' beliefs and practices. In H. Fives \& M. Gregorie Gill (Eds.), International handbook of research on teachers' beliefs (pp. 66-84). New York, NY: Routledge.

Bullough, R. V. Jr., \& Pinnegar, S. (2004). Thinking about the thinking about self-study: an analysis of eight chapters. In J. J. Loughran, M. L. Hamilton, V. K. LaBoskey \& T. Russell (Eds.), International handbook of self-study of teaching and teacher education practices. (1), (pp: 313-342). Dordrecht: Kluwer Academic.

Bullock, D. (2010). Learner self-assessment: An investigation into teachers' beliefs. ELT Journal, 65 (2), 114-125. doi: 10.1093/elt/cccq041

Clarke, D., \& Hollingsworth, H. (2002). Elaborating a model of teacher professional growth. Teaching and Teacher Education, 18(8), 947-967.

Ciani, K. D., Summers, J., \& Easter, M. A. (2008). A "top-down" analysis of high school teacher motivation. Contemporary Educational Psychology, 33 (4), 533-560. doi:10.1016/j.cedpsych.2007.04.002

Cincotta-Segi, A. (2011). 'The big ones swallow the small ones'. Or do they? Language-ineducation policy and ethnic minority education in the Lao PDR. Journal of Multilingual and Multicultural Development. 32. 1-15. 10.1080/01434632.2010.527343.

Creswell J. W. (2013). Nitel araştırma yöntemleri. Ankara: Siyasal Kitabevi.

Czarniawska, B. (2004). Narratives in social science research. Thousand Oaks. CA: Sage.

Denzin, N. K. (1978). The research act: a theoretical introduction to sociological methods. New York: McGraw-Hill.

Ellis, C. (2004). The Ethnographic I. Walnut Creek, CA: Altamira.

Evertson, C., \& Green, J. L. (1986). Observation as inquiry and method. In M. Wittrock (Ed.), The third handbook for research on teaching (pp. 162-213). New York: Macmillan.

Grossman, P. L. (1990) The Making of a Teacher: Teacher Knowledge and Teacher Education. New York: Teachers College.

Hamilton, M. L., \& Pinnegar, S. (2006). Alternative representations of collaboration and community. In D. L. Tidwell, L. M. Fitzgerald, \& M. Heston (Eds.), Journeys of hope: Risking self-study in a diverse world. The proceedings of the fifth international conference of the self-study of teacher education practices, Herstmonceux Castle, East Sussex, England (pp. 118-121). Kingston, ON: Queen's University.

Holt-Reynolds, D., \& Johnson, S. (2002). Revising the task: the genre of assignmentmaking. In C. Kosnik, A. Freese \& A. P. Samaras (Eds.), Making a difference in teacher education through selfstudy (2), (pp. 14-17). Toronto, Ontario: OISE, University of Toronto.

Jorgensen, R., Grootenboer, P., Niesche, R., \& Lerman, S. (2010). Challenges for teacher education: The mismatch between beliefs and practice in remote indigenous contexts. Asia-Pacific Journal of Teacher Education, 38 (2), 161-175. doi: $10.1080 / 13598661003677580$ 
Kagan, D. (1992). Implications of research on teacher belief. Educational Psychologist, 27(1), 65-90.

LaBoskey, V. K. (2004). The methodology of self-study and its theoretical underpinnings. In J. Loughran, M. L. Hamilton, V. K. LaBoskey \& T. Russell (Eds.), International handbook of self-study of teaching and teacher education practices (12), (pp: 817-869). Netherlands: Springer.

Laplante, B. (1997). Teachers' beliefs and instructional strategies in science: Pushing analysis further. Science Education, 81(3), 277-294.

Loughran, J. J. (2004). Learning through self-study: The influence of purpose, participants and context. In J. Loughran, M. L. Hamilton, V. LaBoskey, \& T. Russell (Eds.), International handbook of self-study of teaching and teacher education practices (pp. 151-192). Dordrecht: Kluwer Academic.

Marshall, C., \& Rossman, G. B. (2006). Designing qualitative research. Thousand Oaks, CA: Sage.

Martin, N.S. \& Siry, C. (2012). Using video in science teacher education: an analysis of the utilization of video-based media by teacher educators and researchers. B.J. Fraser et al. (eds.), Second International Handbook of Science Education, Springer International Handbooks of Education 24, DOI 10.1007/978-1-4020-9041-7_29, 417-433.

Mishra, P. \& Koehler, M. J. (2006). Technological pedagogical content knowledge: A framework for integrating technology in teacher knowledge. Teachers College Record, 108(6), 1017-1054.

Mitchell, C., Weber, S., \& Pithouse, K. (2009). Facing the public: using photography for selfstudy and social action. In Tidwell, D. L., Heston, M. L., Fitgerald M. L. (Eds.), Research methods for the self-study of practice (9), (pp: 119-135). USA: Springer.

Mouza, C. (2009). Does research-based professional development make a difference? A longitudinal investigation of teacher learning in technology integration. Teachers College Record, 111 (5), 1195-1241.

National Research Council [NRC]. (2011b). National science education standards. Washington, DC: National Academy.

Nishino, T. (2012). Modeling teacher beliefs and practices in context: A multi methods approach. Modern Language Journal, 96 (3), 380-399. doi: 10.1111/j.15404781.2012.01364.X

Ogan-Bekiroglu, F., \& Akkoc, H. (2009). Pre-service teachers' instructional beliefs and examination of consistency between beliefs and practices. International Journal of Science and Mathematics Education, 7 (6), 1173-1199. doi: 10.1007/s10763-009-9157$\mathrm{z}$

Southerland, S., Gallard, A, \& Callihan, L. (2011). Examining teachers hurdles to "Science for All." International Journal of Science Education, 33 (16), 2183-2213. doi: 10.1080/09500693.2010.530698

Pajares, M. F. (1992). Teachers' beliefs and educational research: Cleaning up a messy construct. Review of Educational Research, 62(3), 307-332.

Rinke, C. R., Gladstone-Brown, W., Kinlaw, C. R. and Cappiello, J. (2016), Characterizing STEM teacher education: affordances and constraints of explicit STEM preparation for elementary teachers. School Science and Mathematics, 116(6), 300-309.

Patton M. Q. (1987). How to use qualitative methods in evaluation. Newbury Park, CA: Sage.

Catherine Kohler Riessman (2008). Narrative Methods for the human sciences. CA, USA: SAGE Publications

Savasci, F., \& Berlin, D. F. (2012). Science teacher beliefs and classroom practice related to constructivism in different school settings. Journal of Science Teacher Education, 23(1), 65-86. doi: 10.1007/s10972-011-9262-z 
Shulman, L. (1986). Those who understand: Knowledge growth in teaching. Educational Researcher, 15(2), 4-14.

Smith, L. (2005). The impact of early life history on teachers' beliefs: In-school and out-of school experiences as learners and knowers of science. Teachers and Teaching, 11(1), $5-36$.

Sprinthall, N. A., Reiman, A. J., \& Thies-Sprinthall, L. (1996). Teacher professional development. In J. Sikula, T. J. Buttery, \& E. Guyton (Eds.), Handbook of research on teacher education (2nd ed., pp. 666-703). New York: Macmillan.

Southerland, S., Gallard, A, \& Callihan, L. (2011). Examining teachers' hurdles to "Science for All." International Journal of Science Education, 33 (16), 2183-2213. doi: 10.1080/09500693.2010.530698

Strauss, A. \& Corbin, J. (1990). Basics of qualitative research: Grounded theory procedures and techniques. New Delhi: SAGE.

Stemler, S. (2001) An overview of content analysis. Practical Assessment, Research \& Evaluation, vol. 7(17). Retrieved January 12, 2017 from http://pareonline.net/getvn.asp?v=7\&n=17

Tang, E. L.-Y., Lee, J. C.-K. \& Chun, C. K.-W. (2012). Development of teaching beliefs and the focus of change in the process of pre-service ESL teacher education. Australian Journal of Teacher Education, 37 (5), 89-107. Retrieved from http://ro.ecu.edu.au/ajte/vol37/iss5/8

Tidwell, D., \& Fitzgerald, L. (2004). Self-study as teaching. In J. Loughran, M. L. Hamilton, V. LaBoskey \& T. Russell (Eds.), International handbook of self-study of teaching and teacher education practices (Vol. 1, pp. 69-102). Dordrecht, The Netherlands: Kluwer.

Tsangaridou, N. (2008). Trainee primary teachers belie fs and practices about physical education during student teaching. Physical Education and Sport Pedagogy, 13 (2), 131-152. doi: 10.1080/17408980701345667

Turner, J. C., Warzon, K., \& Christensen, A. (2011). Motivating mathematics learning: Changes in teachers' practices and beliefs during a nine-month collaboration. American Educational Research Journal, 48 (3), 718-762. doi: 10.3102/0002831210385103

Uzuntiryaki, E., Boz, Y., \& Kirbulut, D. (2010). Do pre-service chemistry teachers reflect their beliefs about constructivism in their teaching practices? Research in Science Education, 40 (3), 403-424. doi: 10.1007/ s11165-009-9127-z.

Yerrick, R., \& Hoving, T. (2003). One foot on the dock and one foot on the boat: Differences among preservice science teachers' interpretations of field-based science methods in culturally diverse contexts. Science Education, 87(3), 390-418.

Yıldırım, A., \& Şimşsek, H. (2013). Sosyal bilimlerde nitel araştırma yöntemleri [Qualitative research methods in Social Sciences]. Ankara: Seçkin Pub..

Yildırım, C. (2011). Bilim Tarihi (14. Basım), İstanbul: Remzi Kitapevi.

Yung, B. H. W., Wong, S. L., Cheng, M. W., Hui, C. S., \& Hodson, D. (2007). Tracking pre service teachers' changing conceptions of good science teaching: The role of progressive refl ection with the same video. Research in Science Education, 37, 239259.

Widjaja, W., Vale, C., Groves, S. \& Doig, B. (2015). Teachers' professional growth through engagement with lesson study. Journal of Mathematics Teacher Education, 20(95), 127.

Wilkins, J. L. M. (2008). The relationship among elementary teachers' content knowledge, attitudes, beliefs, and practices. Journal of Mathematics Teacher Education, 11(2), 139-164. doi: 10.1007/s10857-007-9068-2 